DOI: 10.18778/2084-140X.10.25

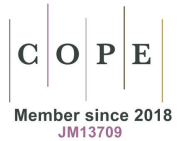

\title{
МАЯ ПЕТровА-ТАНЕвА, Помощница на иарете: св. императрица Теофана в южноставянската традиนия [Maja Petrova-Taneva, Supporter to the Tsars: Saint Empress Theophano in the South Slavic Tradition], Издателски център Боян Пенев, София 2018, pp. 335.
}

I can say without any doubt that the appearance of Maya Petrova-Taneva's book is an event in Bulgarian mediaeval studies, not only in literary and hagiographic fields, but also in areas related to pursuing political ideology and legitimizing power through holiness. It is a comprehensive and exhaustive study of the veneration of a saint, who not only was the wife of one of the most remarkable Roman basileis, but through the presence of her relics in Tărnovgrade has attracted the attention of probably the most remarkable figure of $14^{\text {th }}$ century Bulgaria - Patriarch Euthymius - and enters the pantheon of the Second Bulgarian Empire as an "supporter to the tsars". The book is constructed in a classical way: the study of the life of Empress Theophano preceded the presentation of her worship in the Empire, and then in Bulgaria and Serbia, after which the author proceeded to present the sources for the cult (first prologues, then Vita of the deacon Nicholas and the service of St. Patriarch Euthymius of Tărnovgrade) and even some of the later manifestations of the cult were not ignored. The conclusion presents the results of the research, followed by an appendix that is no less valuable than the study itself because presenting the sources, on which it is based.

Without trying to retell the book and thus deprive the future reader of the pleasure of first contact with it, I shall present some essential elements of this research. The extensive introduction is a detailed overview of the sources and historiography. This is by no means a simple enumeration, but an analytical representation of both the texts on which the study is based and its precursors. Among other things, this section is also an important tool to use in new investigation and understanding the book itself. The first chapter is devoted to the life of the Empress and to a survey of her veneration in the Empire. The life and relations in the imperial court could always be of interest, but especially in some of the more delicate cases that have both political and religious implications. Such is our case, which presents fluctuating moments of sorrow and God's intercession. The narration strictly follows the sources and refers to the relevant literature on the topic. The second part of the chapter presents the Byzantine sources for understanding the veneration of St. Theophano: The Anonymous Life, that of Patriarch Euthymius of Constantinople, the discourse for Empress Theophano by Nicephorus Gregoras, and the Greek service for her. The texts are examined individually and in context so that we can best understand the worship of this remarkable woman.

The second chapter is devoted to the cult of St. Theophano in Bulgaria and Serbia. Here we are facing a later and completely different development. While in the $10^{\text {th }}$ century's Empire it was maintained and held by the authorities with an aim to consolidating the Macedonian dynasty, among the Orthodox southern Slavs, worship was revived on a new basis in order to acquire its own meaning and in its own way to achieve the desired result in strengthening power and society. The beginning is undoubtedly related to a translatio of Saint Theophano's relics in Tărnovgrade, but we do not know the facts in detail. It is important to 
us that this is a continuation of a practice that began at the dawn of the Second Empire and involved the construction of a special pantheon of intercessors of power. The continuation of worship in Vidin and Belgrade is also related to the presence of the relics of St. Theophano in the two capitals and to the efforts of their rulers to collect holiness in their cities. We are interested in the analysis that the author makes of the functioning of the cult and the rise of its political significance among the Slavs, combined with the possible weakening of its importance in Byzantium, which took place gradually after the end of the Macedonian dynasty. This is one of the main messages of the monographic work.

The following chapters focus on exploring the Slavic sources for the worship of St. Theophano. Chapter 3 presents the synaxary readings: The Prologue Vita, the Panegyric discourse of the Bdin Miscellany and so forth. They are presented with the history of the text and the copies, text-critical analysis, comparisons with Greek and other Slavic texts. Chapter 4 is dedicated to the Life of the Saint Empress by Deacon Nicholas, based on its copies in Balkan Cyrillic manuscripts. We find a review of the copies, accompanied by a table of comparisons between them. The Greek prototype, its author and sources were explored, again accompanied by comparative tables presenting borrowings and additions from other texts. Particular attention was paid to the South Slavic translations of the Vita, classified by Maya Petrova-Taneva as $\mathrm{A}$ and $\mathrm{B}$.

The participation of Patriarch Euthymius of Tărnovgrade in the preparation of the texts for the worship of the Holy Empress Theophano is undoubtedly a remarkable fact from the religious, cultural and literary history of the Bulgarian $14^{\text {th }}$ century. The involvement of such a figure in the veneration testifies for the importance given to him in Second Bulgarian Empire. St. Euthymius is central figure not only for the religious but also to the political life of the country, as the creator of a special pantheon of protectors of the tsar and the people at this difficult time. He is the author of St. Theophano's divine service, to which chapter 5 of the book is dedicated, and possibly of a prayer canon of the saint and maybe translator of Vita by Deacon Nicholas. It provides the reader with an extremely interesting analysis and comparison of the text of the service with other works, which not only show interdependencies, but also make it possible to draw parallels with similar cults and their functioning accordingly. A good example of this is the comparison with the veneration of St. Paraskeva-Petka and some elements of the Our Lady's City-protection cult. The last chapter 6 is devoted to the later developments of the cult of St. Theophano in the Balkans. The conclusion presents and summarizes the results achieved in the development of worship of the Holy Empress, highlighting and arranging the conclusions, giving even greater clarity to the presentation.

At the beginning I noted that I consider the appearance of Maya Petrova-Taneva's book a remarkable event in Bulgarian mediaeval studies. I believe that this review confirms my words, but I would also like to add that the book not only reaches interesting and important conclusions, but also gives prospects for further research. After the last chapter of the book there is an annex with texts, some of which published for the first time. This is a significant contribution to the hagiographical studies related to the veneration of St. Theophano: the two synaxary Vitae and the two translations of the Vita of the Holy Empress by Deacon Nicholas, whose Greek prototype has not yet been discovered, as well as the sixth marial miracle with Emperor Leon VI the Wise from the collection of the Our Lady's Miracles by Agapius Landos and several apocryphal prayers to women-saints, including St. Theophano. In fact, the office and the prayer canon to the saint empress were not included, since they were used by other editions and their reissue was not among the tasks of the author. The texts annexed to the study, and especially The Vita of Deacon Nicholas with his two available translations, make the book an indispensable tool for all who will work in the field of medieval Slavic as well as Byzantine hagiography.

I began this brief review by saying that the appearance of Maya Petrova-Taneva's book on the veneration of the Holy Empress Theophano 
in the Empire and among the Southern Slavs was an event in Bulgarian mediaeval studies. I think the suggested observations completely confirm them. However, what is most important for a study is not the accomplished text, but the prospects for future research that it opens. I believe that in this case we have every reason to see them, and some to continue on the right path.

Ivan Biliarsky (Sofia)* iD https://orcid.org/0000-0002-8084-8858

${ }^{*}$ Bulgarian Academy of Sciences, Institute of History 